\title{
Evidence that the corpus luteum of pregnancy contributes to the control of tonic secretion of $\mathrm{LH}$ in the ewe
}

\author{
K. H. Al-Gubory, M. R. Blanc*, J. C. Poirier*, A. Solari and J. Martinet \\ I.N.R.A.-Unité d'Endocrinologie Cellulaire et Moléculaire, 78350 Jouy-en-Josas, France; and \\ *I.N.R.A. Laboratoire de Neuroendocrinologie, 37380 Nouzilly, France
}

\begin{abstract}
Summary. Concentrations of LH and FSH were measured in blood samples collected from the jugular vein at 20-min intervals for $7 \mathrm{~h}(09: 00-16: 00 \mathrm{~h})$ on Days 60, 80, 100 and 120 of pregnancy in 5 intact ewes and 5 from which the CL had been excised on Day 70. In the 5 intact ewes, plasma LH concentrations remained low and unchanged between Days 60 and 120. During this period, pulsatile release of LH occurred irregularly and infrequently. Removal of the CL resulted in an increase in the basal values of LH and in the frequency and amplitude of LH pulses. Concentrations of FSH were relatively constant in all stages of pregnancy examined and were similar in both groups of ewes. These results show that (1) LH concentrations are low during the second half of pregnancy; and (2) LH, but not FSH, increases after CL excision, presumably by removing some luteal factor inhibitor of LH secretion.
\end{abstract}

Keywords: ewe; pregnancy; corpus luteum; FSH; LH

\section{Introduction}

In 1945, Casida \& Warwick reported that ovariectomy performed after Day 55 of pregnancy in the ewe did not always lead to abortion. Ten years later, Denamur \& Martinet (1955) showed that ovariectomy can be performed on or after Day 50 of pregnancy without inducing an abortion and suggested that gestation was maintained by an extra-luteal source of progesterone. In fact, it has been demonstrated that the placenta assumes an active role in progesterone secretion during the last two-thirds of pregnancy (Linzell \& Heap, 1968; Moore et al., 1972). Therefore, the physiological role, if there is any, of the corpus luteum (CL) after Day 50 of pregnancy in ewes is not known.

A recent study of ovarian follicular populations at Day 140 of pregnancy in the ewe has shown that the ovary bearing a CL contained significantly more small preantral follicles $(<0.08 \mathrm{~mm}$ in diameter) than did the ovary without a CL (Al-Gubory \& Martinet, 1987). These results suggest that the CL has a local stimulatory effect on the recruitment of primordial follicles. This hypothesis is supported by the study of follicular populations at Day 140 of pregnancy in unilaterally ovulating ewes from which the $\mathrm{CL}$ was removed at Day 75 ; there was no difference between the ovary with a CL removed and the contralateral ovary in the number of preantral follicles (Al-Gubory et al., 1987). Furthermore, after surgical removal of the CL, it has been demonstrated that the number of preantral follicles, especially those leaving the reserve of primordial follicles, increased in both kinds of ovary. It is apparent that the CL exerts another effect, thereby limiting the recruitment of primordial follicles during pregnancy by a systemic action.

The fact that the total number of preantral follicles decreased in long-term hypophysectomized ewes (Dufour et al., 1979) and that FSH administration for 4 days in the mouse resulted in an increase in the number of small preantral follicles (De Reviers et al., 1984) could be taken as arguments for a role of FSH in early follicular development. 
In view of these observations, it seemed of interest to study the effect of removal of the CL of pregnancy on the secretion of pituitary gonadotrophins.

\section{Materials and Methods}

Animals. Ewes of the Préalpes-du-Sud breed, aged 2-3 years, were housed under conditions of natural light and temperature and provided with a diet (hay, straw and concentrates) adequate for gestation needs. Animals had access to water ad libitum. At Day 70 of pregnancy, anaesthesia was induced with intravenous injection of $120 \mathrm{mg}$ pentobarbital (Sanofi, Paris, France) and $400 \mathrm{mg}$ thiopental (Abbott, Aubervilliers, France), maintained with halothane, and a midventral laparotomy was performed. In 5 ewes (Group L), selected randomly, CL excision was performed by making an incision on the surface of the ovary and exerting pressure with fingers around the base of the CL. Haemorrhage was arrested by local application of thrombin (Houdé, Paris, France). The other 5 ewes (Group C) were assigned to the sham operation which consisted of exposure of ovaries without removal of the CL. All ewes were injected intramuscularly with penicillin $\left(10^{6} \mathrm{U}\right.$ per day) for 3 consecutive days after surgery.

Blood samples. During the breeding season, frequent bleeding $(5 \mathrm{ml})$ consisted of 22 samples taken from the jugular vein into evacuated heparinized tubes every 20 min for $7 \mathrm{~h}(09: 00-16: 00 \mathrm{~h})$ on Days 60, 80, 100 and 120 of pregnancy. Blood samples were kept at $4^{\circ} \mathrm{C}$ before centrifugation $(3000 \mathrm{~g})$ for $30 \mathrm{~min}$. Plasma was stored at $-20^{\circ} \mathrm{C}$ until the hormone concentrations were measured.

LH and FSH assay. To avoid inter-assay variation, all plasma samples were run in duplicate in a single assay for each hormone. Concentrations of LH and FSH were measured by the double-antibody RIA according to the procedure described previously (Pelletier et al., 1968; Blanc \& Poirier, 1979). The intra-assay coefficient of variation was $<12 \%$ for $\mathrm{LH}$ and $<10 \%$ for FSH. The minimum detectable concentration of the $\mathrm{LH}$ assay was $0.2 \mathrm{ng} / \mathrm{ml}$ and that of FSH was $2 \mathrm{ng} / \mathrm{ml}$.

Progesterone assay. Plasma progesterone concentrations were determined for 09:00 h samples in one assay using a previously described double-antibody RIA (Heyman et al., 1984). The intra-assay coefficient of variation and the minimum detectable concentration were $<10 \%$ and $0.2 \mathrm{ng} / \mathrm{ml}$ respectively.

Statistical analysis. The presence, frequency and amplitude of LH and FSH pulses in individual profiles of the 22 blood samples collected from each ewe were determined by the PULSAR program (Merriam \& Wachter, 1982). The $G$ values used in this program were $G(1)=3 \cdot 8, G(2)=2 \cdot 0, G(3)=1 \cdot 5, G(4)=1 \cdot 2$ and $G(5)=1 \cdot 0$. These values specify the number of assay coefficients of variation over a smoothed baseline that 1,2, 3,4 or 5 consecutive elevated points must be to qualify as a pulse. The overall mean concentrations of FSH and LH for the 5 ewes per group were calculated as the average of the 22 samples collected from each ewe during period of sampling. All data were subjected to analysis of variance for repeated measurements using general linear models procedures (SAS, 1987) followed by Duncan's multiple range test. A logarithmic transformation was applied to the data, if necessary, to equalize variances.

\section{Results}

No significant differences were found between ewes in Groups $\mathrm{C}$ and $\mathrm{L}$ in the mean progesterone concentrations for any of the four stages of pregnancy examined (Fig. 1). However, 3 of the 5 Group L ewes and 1 of the 5 Group $C$ ewes had 2 lambs while the other ewes had only 1 lamb and this might explain the variation between ewes in Group $L$ in the concentration of progesterone. The analysis of variance revealed an interaction $(P<0.05)$ between groups by time. This could be explained by the difference between ewes in Groups $\mathrm{C}$ and $\mathrm{L}$ in the evolution of peripheral concentrations of progesterone after Day 60 of pregnancy due to a small, but nevertheless statistically not significant, decrease in mean progesterone concentration 10 days after $C L$ excision ( 4.5 and $3.2 \mathrm{ng} / \mathrm{ml}$ on Days 60 and 80 ). In both groups of ewes, plasma concentrations of progesterone increased markedly after Day 100.

Plasma concentrations of FSH were relatively constant in all stages of pregnancy examined and were similar in the two groups of ewes (Fig. 2). No episodic release of FSH was detected in any of the ewes.

Plasma concentrations of $\mathrm{LH}$ in Group $\mathrm{C}$ ewes were low and remained unchanged (about $0.3 \mathrm{ng} / \mathrm{ml})$ between Days 60 and 120 , but in Group L ewes increased $(P<0.01$, Duncan's multiple range test) from $0.4 \mathrm{ng} / \mathrm{ml}$ at Day 60 (10 days before CL excision) to 0.7 and $0.6 \mathrm{ng} / \mathrm{ml}$ respectively at Days 80 and 100 (10 and 30 days after CL excision) (Fig. 2). 


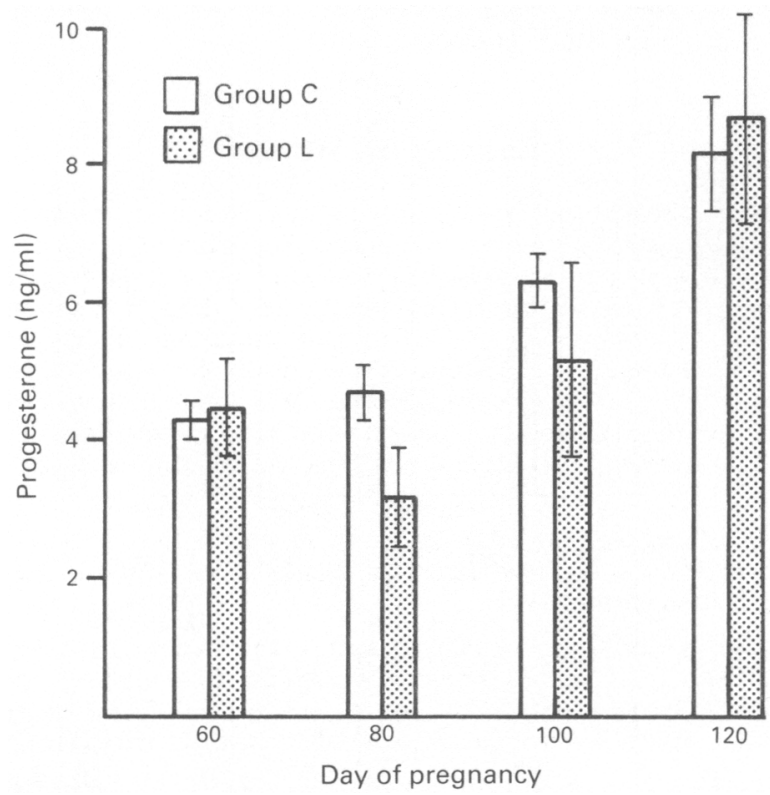

Fig. 1. Mean ( \pm s.e.m.) plasma concentrations of progesterone for 5 intact (Group C) pregnant ewes and 5 ewes from which the CL was removed at Day 70 (Group L).

In intact ewes, occasional LH pulses of low amplitude $(<0.64 \mathrm{ng} / \mathrm{ml})$ were detected in some stages of pregnancy (Fig. 3). The mean frequency (pulses/7 h) and amplitude ( $\mathrm{ng} / \mathrm{ml}$ ) of $\mathrm{LH}$ pulses were relatively stable between Days 60 and 120 (Table 1).

Before CL excision (at Day 60), pulsatile release of LH was infrequent (Fig. 3) and the amplitude of LH pulses detected never exceed $0.64 \mathrm{ng} / \mathrm{ml}$. After CL excision, episodic releases of LH occurred frequently (Fig. 3). Compared to Day 60, LH pulse frequency increased $(P<0.05$, Duncan's multiple range test) at Day 80 (10 days after CL excision). The amplitude of LH pulses increased $(P<0.05) 10$ days after CL excision: $69 \%$ of LH pulses had an amplitude greater than $0.64 \mathrm{ng} / \mathrm{ml}\left(\chi^{2}\right.$ test $)$.

Table 1. Characteristics of LH secretion during the second half of pregnancy for 5 intact ewes (Group C) and 5 ewes from which the CL was removed at Day 70 (Group L)

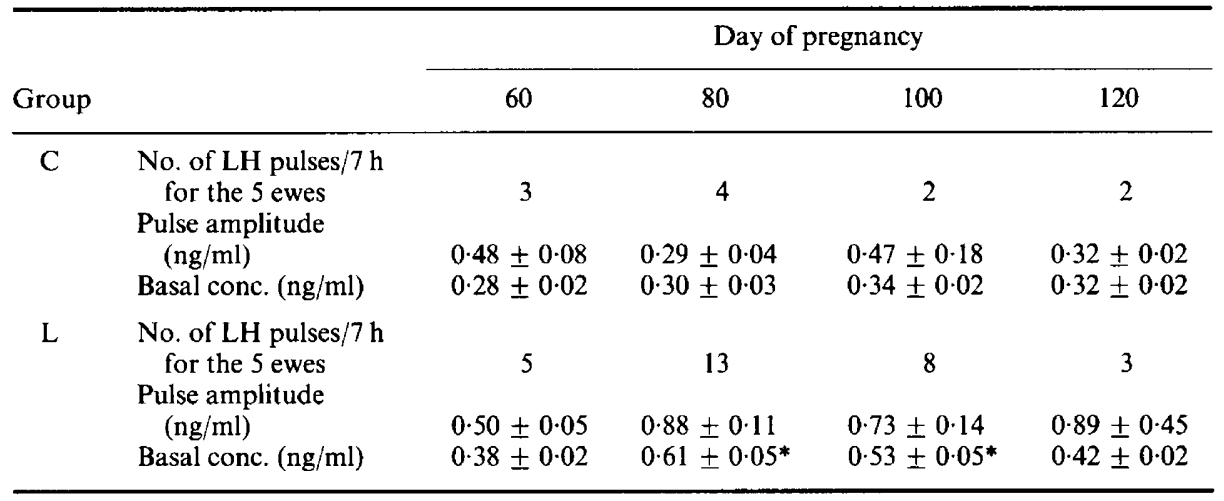

Values are mean \pm s.e.m.

$* P<0.01$ (Duncan's multiple range test) compared to value at Day 60 . 


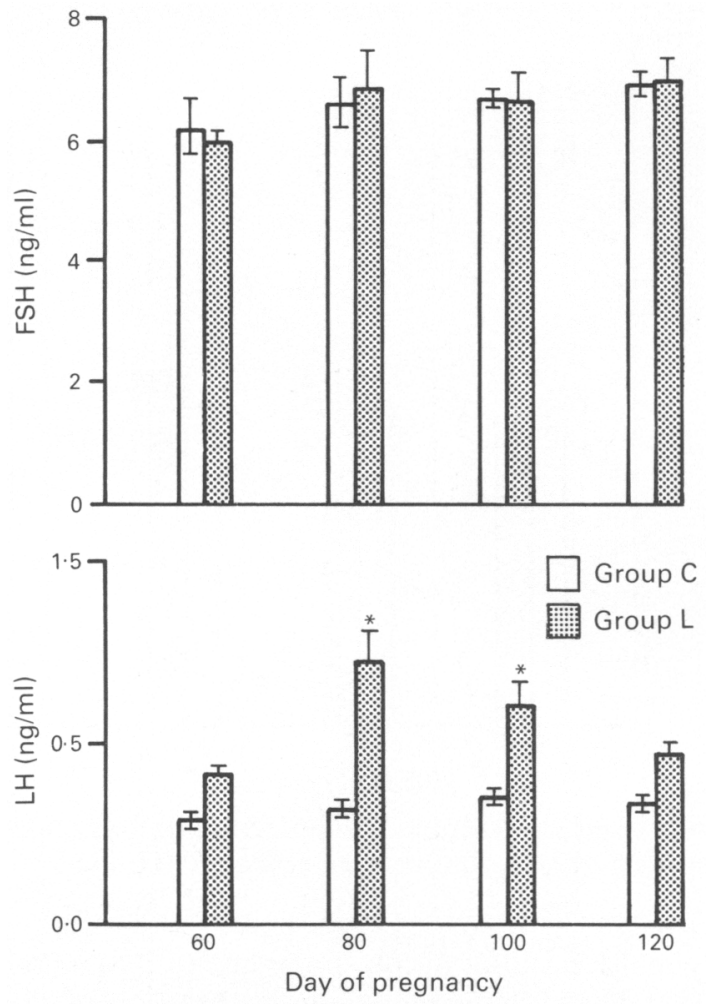

Fig. 2. Mean ( \pm s.e.m.) plasma concentrations of FSH and LH for 5 intact (Group C) pregnant ewes and 5 ewes from which the CL was removed at Day 70 (Group L). *Significantly different from Day $60(P<0.01$, Duncan's multiple range test $)$.

The interaction $(P<0.04$ after square root +0.5 transformation) between groups by time for LH pulse frequency might be explained by the fact that this parameter remained stable between Day 60 and 120 in Group C ewes but increased in Group L ewes (Table 1).

Basal concentrations of LH in Group C ewes were low and remained stable between Days 60 and 120 (Table I). Basal values of LH at Days 80 and 100 (10 and 30 days after CL excision) were significantly greater $(P<0.01$, Duncan's multiple range test) than at Day 60 (10 days before CL excision) (Table 1).

\section{Discussion}

By using frequent bleeding, we have shown that peripheral concentrations of $\mathrm{LH}$ in the ewe during periods when the CL is not necessary for maintenance of pregnancy (i.e. after Day 50) were maintained at low levels with an overall mean of $0.3 \mathrm{ng} / \mathrm{ml}$. This finding is in agreement with a previous study (Alexander et al., 1973) in which only one blood sample was collected at each stage of pregnancy.

There have been two reports in the literature dealing with the episodic release of $\mathrm{LH}$ during pregnancy in ruminants (cow: Little et al., 1982; goat: Buttle \& Morant, 1986). These authors demonstrated that the pattern of LH secretion is pulsatile and Little et al. (1982) also showed that LH pulses frequency and amplitude decrease during the second half of gestation. No information is 


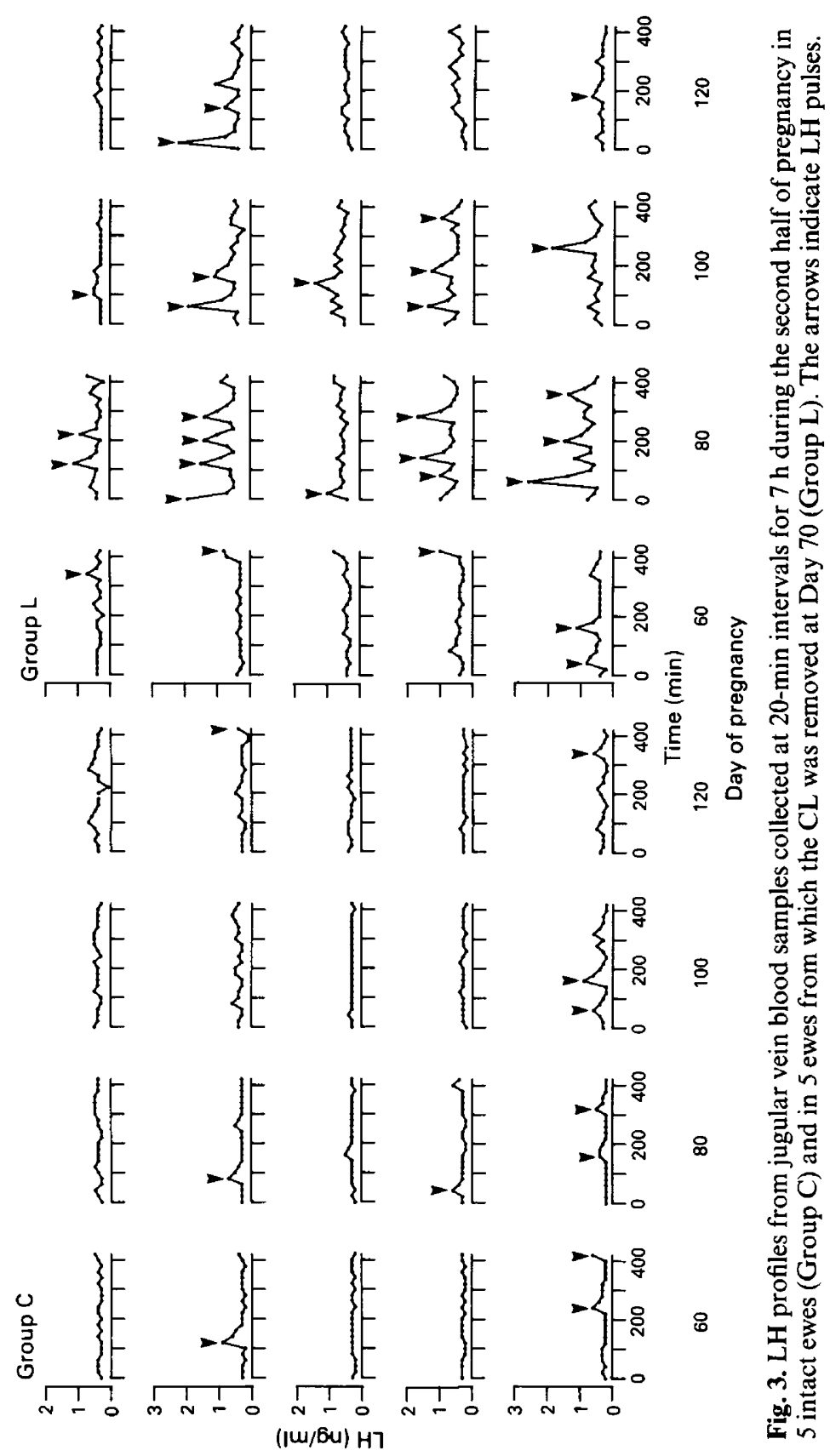


available on the tonic secretion of LH during pregnancy in the ewe. In the present study, we showed by using frequent bleeding that plasma concentrations of $\mathrm{LH}$ are not static during the second half of gestation in the ewe. However, pulsatile release occurred irregularly and infrequently and may reflect reduced pituitary sensitivity to LHRH (Chamley et al., 1974), pituitary content of LH (Chamley et al., 1976) or episodic release of LHRH.

The fact that LH concentrations and pulse frequencies are higher during the follicular phase after luteolysis, when peripheral concentrations of progesterone declined dramatically from about 3 to $0.1 \mathrm{ng} / \mathrm{ml}$, than during the luteal phase of the oestrous cycle in the ewe (Hauger et al., 1977), provide evidence for the role of progesterone in the control of pulsatile discharge of LH. This hypothesis was strongly supported by the finding that treatment of ovariectomized ewes during the breeding season with implants which provided high peripheral progesterone concentrations (3-5 ng/ml) decreased LH pulse frequency (Goodman \& Karsch, 1980; Goodman et al., 1981). These authors showed also that oestradiol administered alone reduced LH pulse amplitude. Goodman et al. (1981) and Martin et al. (1983) found that implants which provided lower progesterone concentrations $(1.3$ and $1.6 \mathrm{ng} / \mathrm{ml}$ respectively) in ovariectomized ewes did not affect LH pulse frequency in the absence of exogenous oestradiol and suggested that oestradiol and progesterone interact synergistically to inhibit the tonic secretion of LH. During the anoestrous season, Goodman et al. (1982) and Tamanini et al. (1986) reported that oestradiol administered alone decreases both frequency and amplitude of LH pulses. During the second half of pregnancy in the ewe, the increasing secretion of oestradiol (Terqui, 1974) and progesterone (Moore et al., 1972; Ricketts \& Flint, 1980) by the placenta may play a major role in suppression of LH secretion to basal levels.

The present study is the first report concerning the effect of removal of the CL on the secretion of pituitary gonadotrophins during pregnancy in the ewe.

The fact that peripheral concentrations of FSH were not affected by CL excision provides a clear demonstration that the bilateral increase in the recruitment of the primordial follicles in ewes with excised CL (Al-Gubory et al., 1987) could not be attributed to increasing secretion of FSH. This finding is consistent with the hypothesis that the passage of follicles from the reserve of primordial follicles to the early growth phase is FSH-independent (Cahill \& Mauléon, 1981).

After surgical removal of the CL at Day 70 of pregnancy, basal concentrations of $\mathrm{LH}$, frequency and amplitude of LH pulses increased considerably. Bilateral ovariectomy performed at Day 75 (Beal et al., 1986) and CL excision at Day 70 of pregnancy in the present study, results in a small transitory decrease in peripheral concentrations of progesterone. In Group L ewes of the present experiment, the concentration of progesterone at Day 80 (10 days after CL excision) was similar to that during the mid-luteal phase of the oestrous cycle (about $3 \mathrm{ng} / \mathrm{ml}$ ), and thereafter increased, reaching 5.2 ng/ml at Day 100 . Nevertheless, LH values on Days 80 and 100 (10 and 30 days after CL excision) were significantly greater than those before CL excision at Day 60. In ewes, oestradiol is secreted exclusively from the large non-atretic antral follicles (Baird \& Scaramuzi, 1976). Since CL excision performed at Day 75 of pregnancy had no subsequent effect on antral follicle population and growth (Al-Gubory et al., 1987) and oestradiol is mainly secreted by the placenta after Day 50, we suspect that surgical removal of the CL of pregnancy in the present study induced a decrease in peripheral oestradiol concentration. Taken together, the results of the present study suggest that some luteal factor, presumably not progesterone, may contribute to the inhibition of LH secretion during the second half of pregnancy in the ewe. The decrease of $\mathrm{LH}$ secretion after treatment of ovariectomized ewes with steroid-free extract of ovine corpora lutea (unpublished data) strongly supports our hypothesis. In ewes with excised CL, the decrease of LH secretion after Day 100 of pregnancy suggests the involvement of extra-ovarian factors from the feto-placental unit in $\mathrm{LH}$ regulation.

K.H.Al-G. was supported by a grant from the French Medical Research Foundation. 


\section{References}

Alexander, D.P., Britton, H.G., Corker, C.S., Naftolin, F. \& Noxon, D.A. (1973) Plasma luteinizing hormone and oestrogen in foetal and maternal sheep. $J$. Endocr. 56, 331-332.

Al-Gubory, K.H. \& Martinet, J. (1987) Effect of the corpus luteum on ovarian follicular populations and growth in the ewe. Anim. Reprod. Sci. 13, 269-281.

Al-Gubory, K.H., Martinet, J., Paly, J. \& Solari, A. (1987) A new concept for control of folliculogenesis during pregnancy in ewes: role of the corpus luteum. Anim. Reprod. Sci. 15, 113-120.

Baird, D.T. \& Scaramuzzi, R.J. (1976) The source of ovarian oestradiol and androstenedione in the sheep during the luteal phase. Acta endocr., Copenh. 83, 402-409.

Beal, W.E., Onthank, D.C. \& Zirkle, S.M. (1986) Effects of human chorionic gonadotropin and cyclic adenosine monophosphate on progesterone secretion by the ovine placenta. J. Anim. Sci. 63, 184-188.

Blanc, M.R. \& Poirier, J.C. (1979) A new homologous radioimmunoassay for ovine follicle stimulatory hormone: development and characterization. Annls Biol. anim. Biochim. Biophys. 19, 1011-1026.

Buttle, H.L. \& Morant, S.V. (1986) The pattern of luteinizing hormone secretion during pregnancy in goats. Anim. Reprod. Sci. 11, 129-137.

Cahill, L.P. \& Mauléon, P. (1981) A study of the population of primordial and small follicles in the sheep. $J$. Reprod. Fert. 61, 201-206.

Casida, L.E. \& Warwick, E.J. (1945) The necessity of the corpus luteum for maintenance of pregnancy in the ewe. J. Anim. Sci. 4, 34-36.

Chamley, W.A., Findlay, K., Cumming, l.A., Buckmaster, J.M. \& Goding, J.R. (1974) Effect of pregnancy on the $\mathrm{LH}$ response to synthetic gonadotropin-releasing hormone in the ewe. Endocrinology 94, 291-293.

Chamley, W.A., Jonas, H.A. \& Parr, R. (1976) Content of $\mathrm{LH}, \mathrm{FSH}$ and growth hormone in the pituitaries of pregnant and anestrous sheep. Endocrinology 98, 1535-1538.

Denamur, R. \& Martinet, J. (1955) Effets de l'ovariectomie chez la brebis pendant la gestation. C. r. hebd. Séanc. Acad. Sci. Paris D 149, 2105-2107.

De Reviers, M.M., Viguier-Martinez, M.C. \& Mariana, J.C. (1984) FSH, LH and prolactin levels, ovarian follicular development and ovarian responsiveness to FSH in the Snell dwarf mouse. Acta endocr., Copenh. 106, $121-126$.

Dufour, J., Cahill, L.P. \& Mauléon, P. (1979) Short- and long-term effects of hypophysectomy and unilateral ovariectomy on ovarian follicular populations in sheep. J. Reprod. Fert. 55, 301-309.

Goodman, R.L. \& Karsch, F.J. (1980) Secretion of luteinizing hormone: differential suppression by ovarian steroids. Endocrinology 107, 1286-1290.

Goodman, R.L., Bittman, E.E., Foster, D.L. \& Karsch, F. (1981) The endocrine basis of the synergistic sup- pression of luteinizing hormone by oestradiol and progesterone. Endocrinology 109, 1414-1417.

Goodman, R.L., Bittman, E.L., Foster, D.L. \& Karsch, F.J. (1982) Alterations in the control of luteinizing hormone pulse frequency underlie the seasonal variation in estradiol negative feedback in the ewe. Biol. Reprod. 27, 580-589.

Hauger, R.L., Karsch, F.J. \& Foster, D.L. (1977) A new concept for control of the estrous cycle of the ewe based on the temporal relationships between luteinizing hormone, estradiol and progesterone in peripheral serum and evidence that progesterone inhibits tonic LH secretion. Endocrinology 101, 807-817.

Heyman, Y., Camous, S., Févre, J., Méziou, W. \& Martal, J. (1984) Maintenance of the corpus luteum after uterine transfer of trophoblastic vesicle to cyclic cows and ewes. J. Reprod. Fert. 70, 533-540.

Linzell, J.L. \& Heap, R.B. (1968) A comparison of progesterone metabolism in the pregnant sheep and goat: sources of production and an estimation of uptake by some target organs. $J$. Endocr. 41, 433-438.

Little, D.E., Rahe, C.H., Fleeger, J.L. \& Harms, P.G. (1982) Episodic release of LH during gestation in the cow. J. Reprod. Fert. 66, 687-690.

Martin, G.B., Scaramuzi, R.J. \& Henstridge, J.D. (1983) Effects of oestradiol, progesterone and androstendione on the pulsatile secretion of luteinizing hormone in ovariectomized ewes during spring and autumn. J. Endocr. 96, 181-193.

Merriam, G.R. \& Wachter, K.W. (1982) Algorithms for the study of episodic hormone secretion. Am. J. Physiol. 243, E310-E318.

Moore, N.W., Barrett, S. \& Brown, J.B. (1972) Progesterone concentration in maternal and foetal blood plasma of ewes. J. Endocr. 53, 187-194.

Pelletier, J., Kann, G., Dolais, J. \& Rosselin, G. (1968) Dosage radioimmunologique de l'hormone luteinisante plasmatique chez le mouton. Mise au point de la technique de dosage. C. r. hebd. Séanc. Acad. Sci., Paris D 266, 2291-2294.

SAS Institute Inc. (1987) SAS/STAT Guide for Personal Computers, Version 6. SAS, Cary.

Ricketts, A.P. \& Flint, A.P.F. (1980) Onset of synthesis of progesterone by ovine placenta. J. Endocr. 86, 337-347.

Tamanini, C., Crowder, M.E. \& Nett, T.M. (1986) Effects of oestradiol and progesterone on pulsatile secretion of luteinizing hormone in ovariectomized ewes. Acta endocr., Copenh. 111, 172-178.

Terqui, M. (1974) Les oestrogènes au cours de la gestation et de la parturition chez la Truie et la Brebis. In Avortement et Parturition provoquée, pp. 71-79. Eds M. J. Bosc, R. Palmer \& C. I. Sureau. Masson, Paris.

Received 15 April 1988 